\title{
Serving PE Teachers' Views on the Interface of Primary and Secondary School PE in Hong Kong 香港在職體育教阬對中小學體育課程鎜接的意見
}

\author{
Chung LI Alberto CRUZ \\ Kevin Wai Keung KAM \\ Department of Health \& Physical Education \\ The Hong Kong Institute of Education, HONG KONG
}

李宗 高達偷 甘偉强

香港教育學院健康與體育學系

\begin{abstract}
This study explored the views of 296 serving physical education (PE) teachers concerning the interface of secondary and primary school PE in Hong Kong. Attached to the interpretive research perspective, questionnaire and follow-up telephone interviews were adopted for soliciting their views on the importance, measures taken and suggestions for improvement. The findings indicated that over $91 \%$ of serving PE teachers acknowledged the importance of interface for facilitating pupils' learning. Similar articulations with the functions and content of school PE that facilitated the interface were found. Although $21 \%$ of them claimed that they had taken some measures for enhancing curricular interface, most of them were not systematic and well-planned. Thus, most PE teachers looked forward to a standardized curriculum stipulated by the Education Bureau as to ensure the effectiveness of the interface. The study suggests reinforcing teachers' awareness of the interface of PE; considering the inclusion of PE in the internal school assessment for the Secondary School Places Allocation System and strengthening the interface from system, school and classroom levels. Consequently, it would enhance the learning and teaching in physical education.
\end{abstract}

Key words: PE teachers, curriculum, interface, transfer, physical education

\section{摘 要}

本文旨在探討296位在職體育教師對中小學體育課程銜接的意見。研究以詮釋理念為依據，透過問卷及跟進電話訪談以顯證 他們對體育課程銜接的重要性、實施措施和改善建議的意見。結果顯示九成一在職體育教師認同銜接對促進學生學習的重要性, 認定學校體育功能和所教授內容相近, 有利相關課程的銜接。雖然有百分之二十一在職體育教師表示已推展一些課程銜接措施, 但有關銜接措施未見系統及計劃推行。大多數體育教師期望教育局能訂定一系列標準課程以確保其成效。本研究建議提升體育教 師對課程銜接的醒覺性, 考慮將體育納入為小學升中呈分試科目之一, 並從系統、學校及課室等層面上優化中小學體育課程的銜 接, 促進學與教。

關鍵詞：體育教師, 課程, 銜接, 轉換, 體育

\section{Introduction}

In most education systems, pupils are required to transit from one school and stage to another. Some transitions are "developmental" resulting inevitably from pupils' growth process with changes in physical, intellectual, social and emotional development. Others are "systemic" caused by respective structures of the education and schools (Anderson, Jacobs, Schramm \& Splittgerber, 
2000). In Hong Kong, pupils usually move from home to kindergarten at the age of 3 , to primary schools at the age of 6 , to secondary (aged 12) and then hopefully to tertiary institutions (18 or 19). In most cases, the interface at various levels of schooling meets with academic, personal, emotional and social transition and adaptation problems. Interface is an important issue for teachers to tackle if pupils' learning is to be maximized (Capel, Zwozdiak-Myers \& Lawrence, 2004; Curriculum Development Council, 2002a; Rudduck, Galton \& Gray, 1998).

\section{Concept and Importance of Interface}

Transfer, transition, continuity, progression, linkage, and interface are commonly and interchangeably used terms on the topic. Demetriou, Goalen and Rudduck (2000) arbitrarily define transfer as "the move from one stage of schooling and from one school to another" and "transition as the move from one year to another within the same school" (p. 425). Benyon (1981) on the other hand, offers a fairly simple and practical definition by saying that continuity is "...the transitions pupils experience from one stage of schooling" (p. 36). The Department of Education and Science (1990) defines progression in terms of pupils' learning as "the sequence built into children's learning through curriculum policies and schemes of work so that later learning builds on knowledge, skills, understandings and attitudes learnt previously" (p. 13). In Hong Kong, the term "interface" is used (Curriculum Development Council, 2002a) to illustrate the importance of linkage of pupils from one stage of schooling to another and hence adopted in this study.

In the context of the United Kingdom, Katene (2000) comments that "the transition of pupils from primary to secondary school is probably the greatest source of discontinuity in the education of pupils" (p. 188). He postulates a number of scenarios which include "being the oldest to the youngest in the school", "being with fewer teachers for everything to having specialist teachers", "being the same group/ class for everything to different groups" and "using modified/ smaller equipment to using full sized equipment". Attending a relatively larger secondary school in terms of space and equipment can be a daunting experience for youngsters. They may be anxious and lost. Some may arrive late for lessons, turn up in the wrong place and forget to bring the correct equipment. Some may be frightened of strict teachers or even worst, bullied by older pupils.
The interface impacts on students' experiences, motivation as well as achievement in all school subjects including physical education (PE) (Warburton \& Spray, 2008). The Curriculum Development Council (2002a) also highlights its importance by suggesting that, "careful handling of the transition helps pupils with different backgrounds and learning needs to build up positive self-esteem and to remain motivated towards learning in school" (p. 1). To facilitate pupils' learning in PE, understanding the current practices and views of $\mathrm{PE}$ teachers' on the interface seems to be necessary.

\section{Research on Interface of PE}

Relatively little research concerning the interface is available in PE. Capel, Zwozdiak-Myers and Lawrence had published a number of related articles aiming to promote continuity and progression of PE for pupils during their transfer from key stage 2 to 3 (primary to secondary) in the context of the UK (Capel, ZwozdiakMyers \& Lawrence, 2003, 2004, 2007). In 2003, they reported their inquiry of PE teachers of 177 secondary schools as well as 538 primary feeder schools from 5 local education authorities. Through questionnaire, they found that $43.8 \%$ secondary and $54.4 \%$ primary school PE teachers had established contacts with their feeder schools. $64 \%$ secondary and $39.6 \%$ primary teachers voiced that they had engaged in liaison activities. However, there was a discrepancy between PE teachers who indicated having some contacts with their primary feeder schools and associated secondary schools. A range of constraints for developing effective liaison activities, in particular, time limit were identified.

In 2004, their focus was on how information about PE was exchanged. They reported that the highest percentage of teachers exchanged information through written document and liaison meetings. Generic information about areas of $\mathrm{PE}$ activities of the National Curriculum and the scheme of work were shared. However, they questioned that "only a small percentage of teachers used the information exchanged to plan for continuity and progression in PE curriculum" (p. 283). Information concerning specific PE content covered or information about individual students like attainment or ability as well as pastoral purposes was limited. They suggested that information should have been used to inform planning for continuity and progression in PE. 
In 2007, Capel, Zwozdiak-Myers and Lawrence published their third article concerning the importance of the curriculum interface of PE. In this small scale qualitative study, 14 secondary school heads of PE department (10 males and 4 females) in five local education authorities in the UK were interviewed. They were asked about their perceived importance, support and constraints of the transfer. They found that "although continuity and progression are promoted in the NCPE (National Curriculum PE), PE heads pay only lip service to it during the transfer from primary to secondary school" (p. 27). Greater emphasis was placed on social/ pastoral support rather than individual pupil's progression and curriculum continuity. Lacking of time to undertake the detailed work needed for curriculum continuity and progression was identified as a constraint factor. To enhance the transfer, PE teachers were recommended to review and put into practice different models. The model suggested by Rudduck, Galton and Gray (1998) was the suggested one that included curriculum continuity, administrative, pedagogical and pupil-centred approaches for exploring the purpose and structure of learning. They also recommended Derricott's (1995) model which composed of 3 facets of interface. "Administrative" interface focused on passing information about pupils. "Curriculum and teaching methods" interface illustrated the forms of curriculum and teaching method continuity. "Social/ pastoral" interface indicated the smooth adaptation of pupils to a new environment. They claimed that the trial of the above models might enhance the development of curriculum continuity and individual pupil progression.

If pupils' PE learning can be successfully progressed from primary to secondary schools, PE teachers have to familiarize with all aspects of the interface. However, very little research information concerning the interface of $\mathrm{PE}$ is available in Hong Kong. How local PE teachers perceive the issue is relatively unknown. It is a timely initiative to launch a study on the topic.

\section{Method}

The study inquired the views of serving PE teachers on the interface of primary and secondary school PE in Hong Kong. The interpretive inquiry was adopted to comprehend how PE teachers had taken measures and viewed the interface of primary and secondary school PE. The central thought of the interpretive inquiry is "hermeneutics" stressing on the importance of understanding and interpreting PE teachers' views. It involves the interplay of meanings between the researcher and PE teachers with the awareness of the context of local PE practices (Bleicher, 1982).

All participants attending the workshops of Summer School for PE Teachers Project were invited to take part in the study. The Summer School for PE Teachers Project was an annual professional development programme initiated by the PE Section, Curriculum Development Institute, Education Bureau of Hong Kong. It provided local PE teachers with opportunity to learn and share with each other innovative school based practices and new PE curriculum initiatives through conference, experience sharing seminar and workshops. It also provided a unique opportunity for collecting and examining PE teachers' views on the interface.

The study composed of 2 phases. In phase 1, the questionnaire technique with both open- and closed-ended questions was adopted. Questionnaire technique was adopted as it was regarded as the quickest means for collecting a large amount of data within a short period of time. Responses of the closed-ended questions were scored on a 5-point Likert-type scale from 1 (strongly disagree) to 5 (strongly agree).

During the questionnaire compilation process, both expert review and pilot study were conducted to ensure its relevance. By using the content analysis, the questionnaire was drafted for soliciting PE teachers' demographical information, their views on the priority of functions of school PE; areas of content taught; importance and current implementation of the interface; and measures to be taken for its successful implementation. Three PE teacher educators and 3 serving PE teachers were invited to review and provide comments on the questionnaire. With their feedbacks, the format and wordings were amended.

Ten PE teachers were invited to participate in the pilot study. They were briefed with the details of the study before completing the questionnaire. A debriefing session was held to discuss the questions. With their inputs, the content, wordings as well as the presentation of the questionnaire were amended and finalized. Descriptive statistical analysis of questionnaire data was performed by using the Statistical Package for Social Sciences (SPSS). It was found that data generated from the questionnaire offered insightful meanings. 
The questionnaire were distributed and collected immediately at the end of each workshop. The timing was thought to be practical. All teachers were briefed with the aims and details of the project, the questionnaire as well as the ethics governing the research.

In the questionnaire, PE teachers were asked to fill in their contacts if they were willing to participate in the follow-up phase II project which concerned the telephone interview. It was regarded as an easy and convenient way to solicit follow-up opinion of PE teachers and supplemented information of the phase I study. Major questions of the telephone interview were compiled as follows:

1. Have you initiated any measures for enhancing the interface of $\mathrm{PE}$ for pupils from primary to secondary school?

2. What kinds of measures have been adopted to promote the continuity and progression of $\mathrm{PE}$ learning experiences?

3. What are your suggestions for enhancing the interface of pupils' PE learning experiences?
Data of the closed-ended questions of the questionnaire were coded and analysed by using the SPSS. Descriptive statistics in terms of frequency and percentage were calculated and presented. Qualitative data of the open-ended questions and telephone interviews were analysed by means of content analysis, constant comparison, theme development and verification techniques (Strauss \& Corbin, 1998).

Concerning the research ethic, the rights of all participants, their anonymity and confidentiality were ensured by all means. Pseudonyms of interviewee 1 to Interviewee 30 were used for the telephone interviewees.

\section{Results and Discussion}

\section{Demographical Information of the Respondents}

Questionnaires were distributed to 296 serving PE teachers who participated in the workshops. With the response rate of $98.31 \%, 291$ questionnaires were returned during the phase 1 study. The genders of the respondents were fairly equal with 143 (49\%) males and $148(51 \%)$ females. Their teaching experiences also spread evenly with $33 \% \quad(n=95)$ of the sample having 9 years or less teaching experience, 36\% ( $n=106)$ were with 10-18 years while $30 \%(\mathrm{n}=87)$ had 19 or more years of teaching experience (Table 1).

Table 1. Statistical Distribution the Years of Teaching Experience of the Participants.

\begin{tabular}{|lll|lll|lll|}
\hline $0-3$ yr. & $14 \%$ & $\mathrm{n}=40$ & $4-6$ yr. & $9 \%$ & $\mathrm{n}=26$ & $7-9$ yr. & $10 \%$ & $\mathrm{n}=29$ \\
\hline $10-12$ yr. & $11 \%$ & $\mathrm{n}=33$ & $13-15$ yr. & $13 \%$ & $\mathrm{n}=38$ & $16-18$ yr. & $12 \%$ & $\mathrm{n}=35$ \\
\hline $19-21$ yr. & $11 \%$ & $\mathrm{n}=32$ & 22 or over & $19 \%$ & $\mathrm{n}=55$ & NA & $1 \%$ & $\mathrm{n}=3$ \\
\hline
\end{tabular}

There was a bit more respondents currently teaching PE in secondary school $(50.5 \% ; n=147)$ while those primary school PE teachers accounted for about $40.5 \%$ ( $n=118)$ leaving $4.8 \%(\mathrm{n}=14)$ teaching both primary and secondary PE class and $2.4 \%(n=7)$ in special schools.

The follow-up phase II telephone interview included 30 volunteered participants in which $70 \% \quad(n=21)$ were male and $30 \%(n=9)$ were female. $46 \%(n=14)$ were primary school PE teachers while 54\% (n=16) were their secondary counterparts. $40 \% \quad(n=12)$ of them were with 0-9 years of teaching experience, $43 \% \quad(n=13)$ taught for 10 to 18 years and $17 \%(n=5)$ were experienced PE teachers who had taught for more than 19 years. The percentage fairly matched with those of the respondents in the phase I study.
Generally speaking, the profiles of PE teachers in this study were quite evenly distributed in terms of their gender, teaching experience and levels of classes taught. Most of them might be regarded as progressive and motivated PE teachers as they were willing to attend the workshops during their summer vacation.

\section{The Importance of Interface of Primary and Secondary School PE Curriculum}

When being asked to rate the importance of the interface of primary and secondary school PE curriculum in the questionnaire, both secondary (91\%) and primary (89\%) school PE teachers strongly agreed and agreed with its importance. Only $1 \%(\mathrm{n}=2)$ articulated their answer as "Not agree" and another $2 \%(\mathrm{n}=2)$ as "Strongly disagree" while those articulated with "NA" (not applicable) accounted for $7 \% \quad(n=20)$. 
However, the results of the follow-up telephone interview of the phase II study revealed that considerable number of interviewees did not aware the issue of the interface. They kept on asking what the meaning of interface was $(n=8)$.

Others concerned much on the difficulties of initiating interface activities. Interviewee 12 complained, "What can we do? There are no resources like money, venue and equipment". Interviewee 18 frankly admitted that his position in school could be a hinder, "it is not easy to initiate measures for enhancing interface. We, PE teachers, get little chance to involve in school administration." Interviewee 9 commented, "I am only a small potato in my school".

As a matter of fact, secondary schools in Hong Kong commonly admitted pupils from a number of primary schools all over Hong Kong and it made the interface more difficult. The following interviewing scripts were quoted for illustration:

"Very difficult as we don't know exactly what the feeder schools are." (Interviewee 8)

"It is hard to launch the interface as pupils come from a number of feeder schools." (Interviewee 27)

"Very difficult, as pupils come from primary schools all over Hong Kong." (Interviewee 29)

Although PE teachers in this study frankly pointed out those constraints for initiating measures to enhance interface, they appeared to be unaware of the issue - the interface. Their awareness of the importance of interface for maximizing pupils' PE learning has to be attended.
Inclusion of $\mathrm{PE}$ as a Subject in the Internal Assessment for the Secondary School Places Allocation System

In Hong Kong, primary six pupils are allocated to different secondary schools under the Secondary School Places Allocation system (SSPA). The allocation is determined in accordance with the three internal assessment results. The subjects assessed are Chinese, English, Mathematics, General Studies, Music and Visual Arts but not PE.

In this study, PE teachers were asked whether they would like to include PE in the internal assessment for the SSPA. 55\% $(\mathrm{n}=160)$ of the respondents strongly agreed and agreed with the inclusion while $16 \% \quad(\mathrm{n}=47)$ disagreed with the inclusion, leaving $28 \% \quad(n=81)$ showing no preference on this issue. Further breaking down of the statistics illustrated that more secondary school PE teachers $(70 \%, \mathrm{n}=89)$ supported the idea of having PE as a subject in the school internal assessment for the SSPA when compared with $46 \% \quad(n=55)$ primary school counterparts (Table 2).

It appeared that primary and secondary school PE teachers in this sample perceived differently on the issue. As PE was not included as the subject in the internal assessment for the SSPA, the assessment practices were found largely inconsistent and with variance among schools. Accordingly, the PE curricular practices became highly individualized or school-based. Consequently, promoting effective interface from primary to secondary school became more difficult and most of the time overlooked.

Table 2. Teachers' View on their Support of Inclusion of PE as a Subject in the Internal Assessment for the Secondary School Places Allocation System.

\begin{tabular}{|l|c|c|c|c|c|c|}
\hline & $\begin{array}{c}\text { Strongly } \\
\text { Agree }\end{array}$ & Agree & No Preference & Disagree & $\begin{array}{c}\text { Strongly } \\
\text { Disagree }\end{array}$ & Total Respondents \\
\hline $\begin{array}{l}\text { Primary school } \\
\text { PE teachers }\end{array}$ & $14 \%, \mathrm{n}=17$ & $\begin{array}{c}32 \%, \\
\mathrm{n}=38\end{array}$ & $27 \%, \mathrm{n}=32$ & $22 \%, \mathrm{n}=26$ & $1 \%, \mathrm{n}=5$ & 118 \\
\hline $\begin{array}{l}\text { Secondary } \\
\text { school PE } \\
\text { teachers }\end{array}$ & $23 \%, \mathrm{n}=34$ & $\begin{array}{c}37 \%, \\
\mathrm{n}=55\end{array}$ & $29 \%, \mathrm{n}=43$ & $9 \%, \mathrm{n}=13$ & $1 \%, \mathrm{n}=3$ & 148 \\
\hline $\begin{array}{l}\text { Primary \& } \\
\text { Secondary PE } \\
\text { teachers }\end{array}$ & $25 \%, \mathrm{n}=3$ & $\begin{array}{c}25 \%, \\
\mathrm{n}=3\end{array}$ & $33 \%, \mathrm{n}=4$ & $8 \%, \mathrm{n}=1$ & $8 \%, \mathrm{n}=1$ & 12 \\
\hline $\begin{array}{l}\text { Special School } \\
\text { PE teachers }\end{array}$ & $\begin{array}{l}14 \%, \\
\mathrm{n}=1\end{array}$ & $\begin{array}{c}71 \%, \\
\mathrm{n}=5\end{array}$ & $14 \%, \mathrm{n}=1$ & $0 \%, \mathrm{n}=0$ & $0 \%, \mathrm{n}=0$ & 7 \\
\hline
\end{tabular}




\section{The Functions of School PE}

When being asked to rate the priority of functions of school PE, 58\% $(n=68)$ primary and 67\% $(n=100)$ secondary school PE teachers put "building healthy and active lifestyle" and "improving physical fitness and bodily coordination" (64\%, $\mathrm{n}=76$ primary and $56 \%, \mathrm{n}=82$ secondary) as their first and second "very important" and "important" functions of school PE (Table 3).

The findings were predictable as "health" and "physical fitness" have long been accepted as major goals of school PE. The Curriculum Development Council (2002b) also recommends that "PE curriculum aims to help students: good health, physical fitness and body co-ordination through an active lifestyle" (p. 13). Moreover, a lot of health and fitness promotion initiatives such as School Physical Fitness Award Scheme, Jump Rope for Heart, SportACT and morning exercise programmes etc. were promoted and developed successfully in schools in the past decades.

$29 \%(\mathrm{n}=35)$ primary and $24 \%(\mathrm{n}=25)$ secondary school PE teachers ranked "learning sports skills" as the 3rd and 4th function in the priority list respectively. The multi-activity model commonly adopted by most PE teachers in Hong Kong was postulated as the major reason. As PE teachers were recommended "to develop basic skills in at least eight different physical activities from not less than 4 areas" (Curriculum Development Council, 2002b, p. 16), short teaching units had commonly been structured and were found to be less capable of helping pupils to improve their sports skills proficiency.

There was a great difference on rating of the function of "nurturing positive values and attitude" between 6\% $(\mathrm{n}=6)$ primary and 33\% $(\mathrm{n}=49)$ secondary school PE teachers (Table 3). Perhaps, the secondary school PE teachers encountered more pupils' discipline problems.

Only 7\% primary and $8 \%$ secondary school PE teachers related "knowledge acquisition" as an important function of $\mathrm{PE}$ in schools (Table 3). It was not sure whether the dualistic conception of $\mathrm{PE}$ was the major cause or not. Some PE teachers might still believe strongly in the "education of physical" conception. Any lessons without physical exertion would not be regarded as "real" PE lessons.

Surprisingly, only $1 \%$ of primary and secondary school PE teachers regarded "promoting generic skills" as an important function although it has been promoted extensively in the education reform for achieving "learning to learn" and "lifelong learning" capabilities in the past decade (Table 3).

Primary and secondary school PE teachers appeared to have similar preference of the purposes of school PE. The similarity of views might be regarded as a facilitating factor for the interface of primary and secondary school PE.

Table 3. Comparison of the Views on the Functions of School PE between Primary and Secondary School PE Teachers.

\begin{tabular}{|l|c|c|c|c|}
\hline Functions of School PE & \multicolumn{2}{|l|}{$\begin{array}{l}\text { Primary School PE Teachers } \\
\text { (n=118) } \\
\text { Very } \\
\text { Important / Important }\end{array}$} & $\begin{array}{l}\text { Secondary School PE Teachers } \\
\text { (n=148) } \\
\text { Very } \\
\text { Important } / \text { Important }\end{array}$ \\
\hline Building Active and Healthy Lifestyle & $40 \%, \mathrm{n}=47$ & $18 \%, \mathrm{n}=21$ & $49 \%, \mathrm{n}=73$ & $18 \%, \mathrm{n}=27$ \\
\hline $\begin{array}{l}\text { Improving Physical Fitness and } \\
\text { Bodily Coordination }\end{array}$ & $32 \%, \mathrm{n}=38$ & $32 \%, \mathrm{n}=38$ & $20 \%, \mathrm{n}=29$ & $36 \%, \mathrm{n}=53$ \\
\hline $\begin{array}{l}\text { Nurturing Positive Values and } \\
\text { Attitudes }\end{array}$ & $3 \%, \mathrm{n}=3$ & $3 \%, \mathrm{n}=3$ & $15 \%, \mathrm{n}=22$ & $18 \%, \mathrm{n}=27$ \\
\hline Learning Sports Skills & $10 \%, \mathrm{n}=12$ & $19 \%, \mathrm{n}=23$ & $9 \%, \mathrm{n}=13$ & $15 \%, \mathrm{n}=22$ \\
\hline Acquiring PE Related Knowledge & $3 \%, \mathrm{n}=3$ & $4 \%, \mathrm{n}=5$ & $3 \%, \mathrm{n}=4$ & $5 \%, \mathrm{n}=8$ \\
\hline Promoting Generic Skills & $1 \%, \mathrm{n}=1$ & $0 \%, \mathrm{n}=0$ & $0 \%, \mathrm{n}=0$ & $1 \%, \mathrm{n}=1$ \\
\hline
\end{tabular}




\section{PE Content Currently Taught}

The analysis of the questionnaire results illustrated that primary and secondary school PE teachers included 10 similar areas of teaching in PE curriculum. Athletics was on the top of the ladder with $86 \%$ primary and 93\% secondary school PE teachers. Basketball came next when being chosen by $80 \%$ primary and $92 \%$ secondary PE teachers as the most popular ball games taught. It was followed by "volleyball" (65\% primary and 86\% secondary), "football" (64\% primary and 65\% secondary), "physical fitness" (58\% primary and 77\% secondary), "gymnastics" (69\% primary and 52\% secondary) and "badminton" (58\% primary and $68 \%$ secondary). Just over $50 \%$ of them $(51 \%$ primary and 52\% secondary) incorporated "table tennis" in their PE teaching (Table 4).
However, "rope skipping" (73\%) and "western folk dance $(29 \%)$ were more popular in primary schools while "handball" (59\%) and "tennis" (42\%) were commonly taught in secondary schools (Table 4).

Similar PE content currently taught in both primary and secondary schools made the planning for vertical progression and continuity of $\mathrm{PE}$ content readily feasible. However, information concerning specific themes within the same content area taught was not the focus of this study. Whether there was any progression in the depth of the PE curriculum content taught in the primary and secondary school PE was relatively unknown.

Table 4. Comparison of Top 10 Popular PE Content Taught in Primary and Secondary Schools.

\begin{tabular}{|l|l|l|l|}
\hline PE Content Taught & $\begin{array}{l}\text { Primary School PE } \\
\text { Teachers }(\mathbf{n}=\mathbf{1 1 8})\end{array}$ & $\begin{array}{l}\text { PE Content } \\
\text { Taught }\end{array}$ & $\begin{array}{l}\text { Secondary School PE } \\
\text { Teachers }(\mathbf{n}=\mathbf{1 4 8})\end{array}$ \\
\hline 1 Athletics & $86 \%, \mathrm{n}=102$ & 1 Athletics & $93 \%, \mathrm{n}=137$ \\
\hline 2 Basketball & $80 \%, \mathrm{n}=94$ & 2 Basketball & $92 \%, \mathrm{n}=136$ \\
\hline 3 Rope Skipping & $73 \%, \mathrm{n}=86$ & 3 Volleyball & $86 \%, \mathrm{n}=128$ \\
\hline 4 Gymnastics & $69 \%, \mathrm{n}=82$ & 4 Physical Fitness & $77 \%, \mathrm{n}=114$ \\
\hline 5 Volleyball & $65 \%, \mathrm{n}=77$ & 5 Football & $65 \%, \mathrm{n}=96$ \\
\hline 6 Football & $64 \%, \mathrm{n}=76$ & 6 Badminton & $68 \%, \mathrm{n}=100$ \\
\hline 7 Physical Fitness & $58 \%, \mathrm{n}=69$ & 7 Handball & $59 \%, \mathrm{n}=88$ \\
\hline 8 Badminton & $58 \%, \mathrm{n}=68$ & 8 Table Tennis & $53 \%, \mathrm{n}=79$ \\
\hline 9 Table Tennis & $51 \%, \mathrm{n}=60$ & 9 Gymnastics & $52 \%, \mathrm{n}=77$ \\
\hline 10 Western Folk Dance & $29 \%, \mathrm{n}=34$ & 10 Tennis & $42 \%, \mathrm{n}=62$ \\
\hline
\end{tabular}

\section{Some Forms of Interface of PE Curricular Between Primary and Secondary Schools}

Just over one fifth $(21 \%, n=61)$ of PE teachers claimed that they had initiated some measures to enhance the interface of primary and secondary school PE. On the contrary, $78 \% \quad(n=226)$ of them had not initiated any interface activities while those who rated with the "NA" accounted for $1 \%(n=4)$. When compared with Capel et al's (2003) study illustrating $43.8 \%$ secondary and 54.4\% primary school PE teachers had already established contacts with their feeder schools in the UK, efforts for enhancing local PE teachers' awareness of the interface might be needed.

In the open-ended questions, some regarded contacts through telephone and email, discussion during tea time, in the Internet, forum, Summer School workshops, social gathering and inter-school competition as interface activities. They then took these opportunities to exchange teaching and learning ideas and share lesson plans. Some of them also relied on asking pupils about their learning and adopted a spiral curriculum for enhancing the interface of primary and secondary PE curriculum.

The analysis generated in the phase II telephone interview illustrated similar results. $23 \%(\mathrm{n}=7)$ of $\mathrm{PE}$ teachers indicated that they had some forms of interface activities, leaving $77 \% \quad(n=23)$ of them with the opposite answer. They communicated and shared information during sports competitions in the same district and alumni meetings (Interviewee 11, 13, 18), open day (Interviewee 2, 10), and invitation relay (Interviewee 3, 7). 2 interviewees (1, 15) voiced that they met their primary school counterparts periodically to discuss with their PE curricula within their schools. However, relatively little in details of the interface was provided. 
Nevertheless, these types of interface activities were casual, private, informal and social in nature. It appeared that little systematic, purposeful pre-planning and exchange of information was evident. It illustrated that the awareness of the importance of interface has to be enhanced among PE teachers.

\section{Measures to Improve the Interface of $\mathrm{PE}$ Curriculum}

In response to the open-ended questions of the questionnaire for recommending measures for enhancing the interface, PE teachers highlighted 2 levels of work to be done. They suggested that the Government should take up the lead by composing a centralized curriculum; structuring areas and content in accordance with respective form levels similar to that of the English, Chinese and Mathematics. Standardized yearly planning and progressions of PE content for primary and secondary schools should be issued. In so doing, PE teachers could have a standardized syllabus to follow. With clear guides for pupils' learning, the interface between primary and secondary could be enhanced. The following telephone dialogues taken in the phase II study were quoted for illustration:

\section{Table 5. PE Teachers' Suggestion of the Government in Taking the Lead for Enhancing Interface of PE Curriculum.}

\begin{tabular}{|l|l|}
\hline Interviewee & Claims \\
\hline 6,25 & "Interface should not be a problem if everything is decided by the central government." \\
\hline 7 & "The interface should be based on the curriculum guide issued by the EDB." \\
\hline 16 & "There should be an overall curriculum guide for schools to follow." \\
\hline 12 & $\begin{array}{l}\text { "The problem of interface could only be solved by the Government. The issuing of the } \\
\text { direction, amending the policy and having standardized curriculum are decisive." }\end{array}$ \\
\hline
\end{tabular}

In the telephone interview of the phase II study, they also recommended measures to be initiated at school and teacher levels. They included formulating policies for improving communications between primary and secondary school PE teachers; organizing more joint sharing sessions, meetings, workshops and seminars, and developing a discussion board on the internet.

It was interesting to find that PE teachers' suggestions on measures to be taken for enhancing the interface relied much on Government and school level. They seldom took active role in articulating measures. It might further illustrate that PE teachers had not been empowered with knowledge and skills to tackle and enhance the interface although they were aware the importance of interface and its contribution towards pupils' PE learning.

\section{Conclusion and Recommendations}

Most of the serving PE teachers in this study supported the importance of the interface of primary and secondary school PE for maximizing pupils' learning.
Primary and secondary school PE teachers were found having different views on the inclusion of the subject in the internal assessment for the SSPA. It may be the suitable time for considering its inclusion. In so doing, the inconsistence and variance of PE curricular and assessment practices among schools can be minimized. The enhancement of interface of primary to secondary school PE would be facilitated.

Primary and secondary school PE teachers had similar articulation of the functions of school PE. They rated "building healthy and active lifestyle" and "improving physical fitness and bodily coordination" as the most important function while "knowledge acquisition" and "promoting generic skills" were ranked as the lowest.

Besides, similar PE contents like athletics, basketball, volleyball, football, physical fitness, gymnastics, table tennis and badminton appeared to be the common areas of PE teaching. Rope skipping and western folk dance were more popular for primary schools while handball and tennis were commonly taught in secondary schools. Similarities in perspective and contents taught between both primary and secondary school facilitated the vertical progression and continuity of school PE. 
Only about one fifth of the PE teachers claimed to have some kinds of interface activities like exchange of teaching and learning ideas through telephone and internet. They had discussions when attending staff development functions and inter-school activities. Such exchanges of information were found not to be systematic and purposeful. Thus, curricular developers and administrators should provide PE teachers with more chances to share and to talk. Moreover, staff development programmes concerning interface should also be well planned.

Furthermore, measures in terms of policies and practices for enhancing the interface have to be formalized. Schagen and Kerr (1999) suggested that at the system level, the directions from government such as formulating curriculum guide, the assessment, the learning outcome frameworks and the learning portfolio among different levels of schooling have to be clustered in a more systemic way. For the school level, initiatives for linking schools and PE departments of primary and secondary school together have to be structured. At classroom level, the culture and practices of sharing of PE data between primary to secondary schools for facilitating the interface are suggested.

The Curriculum Development Council of Hong Kong (2002a) recommends that secondary schools should have policy and action plan for interface. They should adopt a comprehensive and cooperative approach among all stakeholders in school. Secondary schools were suggested to "initiate induction for secondary one students before the end of primary six summer vacation", "maintain close tie with primary schools", "ensure appropriate curriculum practices in secondary one to dovetail with the previous learning experiences of the children in primary schools", and "promote home-school co-operation" (p. 1-7). The suggestions are practical and can provide schools with hints for implementing and facilitating the interface.

Since interface is regarded as important phase for pupils' learning, it is worth to be discussed in details in the near future. Questions like "Are we going to use all or some of the approaches mentioned above?", "What types of local mechanisms do we need to establish for using these approaches?", "What can the Education Bureau do for enhancing the interface?", "What action plans and practices can schools and PE teachers perform for enhancing the interface?" and "Should PE be included as a subject in the internal assessment for the
SSPA?" are needed to be tackled. It is hoped that the interface between primary and secondary school PE can be successfully enhanced and eventually pupils' learning experiences can be enriched and maximized.

\section{References}

Anderson, L.W., Jacobs, J., Schramm, S., \& Splittgerber, F. (2000). School transitions: Beginning of the end or a new beginning? International Journal of Educational Research, 33(4), 325-339.

Benyon, L. (1981). 'Curriculum continuity', Education: 312, 9(2), 36-41.

Bleicher, J. (1982). The hermeneutic imagination, London: Routledge and Kegan Paul.

Capel, S., Zwozdiak-Myers, P., \& Lawrence, J. (2003). A study of current practice in liaison between primary and secondary schools in physical education, European Physical Education Review, 9(2), 115-134.

Capel, S., Zwozdiak-Myers, P., \& Lawrence, J. (2004). Exchange of information about physical education to support primary and secondary school. Educational Research, 46(3), 283-300.

Capel, S., Zwozdiak-Myers, P., \& Lawrence, J. (2007). The transfer of pupils from primary to secondary school. A case study of a foundation subject: Physical education. Research in Education, 77, 14-30.

Curriculum Development Council (2002a). Basic education curriculum guide-building the strength (Primary 1 - Secondary 3): 9 interfaces at various levels of 12 schooling-supporting transition. Hong Kong: Government Printer.

Curriculum Development Council (2002b). Physical education: Key learning area curriculum guide (Primary one to Secondary three). Hong Kong: Government Printer.

Demetriou, H., Goalen, P., \& Rudduck, J. (2000). Academic performance, transfer, transition and friendship: Listening to students' voice. International Journal of Educational Research, 33(4), 425-441. 
Derricott, R. (1995). Curriculum continuity: Primary to secondary. Slough: NFER-Nelson.

Department of Education and Science (1990). Starting with quality: Report of the committee of enquiry into quality of educational experiences offered to 3-4 year olds. Londen: HMSO.

Katene, W. (2000). Progression and continuity in physical education between primary and secondary school. In S. Capel \& S. Piotrowski (Eds). Issues in physical education (pp. 188-205). London: Routledge Falmer.

Rudduck, J., Galton, M., \& Gary, J. (1998). 'Lost in the maze of the new'. Times Educational Supplement, 4299, 19.

Schagen, S., \& Kerr, D. (1999). Bridging the gap? The National Curriculum and progression from primary to secondary school. Slough: NFEA.

Strauss, A. L., \& Corbin, J. (1998). Basics of qualitative research: Techniques and procedures for developing grounded theory (2nd ed.). Thousand Oaks, Calif.: Sage Publications.

Warburton, V., \& Spray, C. (2008). Motivation in physical education across the primary-secondary school transition. European Physical Education Review, 14(2), 157-178.

\section{Acknowledgement}

The authors would like to express their sincere gratitude to the PE Section, Curriculum Development Institute, Education Bureau of the Hong Kong Government for funding this study as part of the Summer School for PE Teachers Project.

\section{Correspondence}

Contact Person: Dr. LI Chung

聯絡人：李宗博士

Telephone : (852) 29487837

Fax $\quad: \quad$ (852) 29487848

E-mail : cli@ied.edu.hk

Address : Department of Health and Physical Education,

Hong Kong Institute of Education, Tai Po, N.T. Hong Kong. 